\title{
SOIL MOISTURE DYNAMICS IN LEVEES DURING FLOOD EVENTS - VARIABLY SATURATED APPROACH
}

\author{
DAVID ZUMR, MILENA CÍSLEROVÁ
}

Czech Technical University in Prague, Faculty of Civil Engineering, Dept. of Irrigation, Drainage and Landscape Engineering, Thákurova 7, 16629 Prague 6, Czech Republic; Mailto: david.zumr@fsv.cvut.cz

Growing occurrence of extreme floods in the Czech Republic has attracted attention to the security of protective earthfill embankments along the rivers. A suddenly increased amount of water on the waterside slope of the embankment may have destroying or even catastrophic consequences. Predictions of seepage patterns through the earth body are usually done considering the saturated flow beneath the free water level only, neglecting the saturated-unsaturated character of the soil water dynamics within earthfill dams.

The importance of water dynamics within an earth dam is known and may be addressed using numerical simulation models. In this study the solution based on transient simulation of seepage through protection levee using saturated-unsaturated theory is presented. Simulations were carried out by a two-dimensional numerical model based on Richards' equation for water flow in porous medium.

It has been shown that proposed approach is, with certain limitations, suitable for large scale engineering applications.

KEY WORDS: Floods, River Embankment, Earth Dam, Unsaturated Soil, Vadose Zone, Seepage Modelling, Soil Water Dynamics, Richards’ Equation.

David Zumr, Milena Císlerová: DYNAMIKA VODNÍHO REŽIMU V TĚLESE OCHRANNÉ HRÁZE BĚHEM POVODNĚ S UVÁŽENÍM NENASYCENÉHO PROUDĚNÍ. J. Hydrol. Hydromech., 58, 2010, 1; 24 lit., 5 obr., 1 tab.

Vyšší pravděpodobnost výskytu extrémních klimatických jevů obrací pozornost k ochraně před následky, které tyto jevy způsobují. Zájem se soustředí na protipovodňové ochranné zemní hráze a jejich bezpečnost při povodních. Výpočet průsaku zemními hrázemi se často omezuje pouze na tu část hráze, která byla plně nasycená vodou, to znamená na plně nasycené proudění. Tento způsob modelování průsaku je dodnes považován za standardní, přestože je velmi limitující. Bez zahrnutí nenasycené části tělesa hráze je zanedbán vliv časově i prostorově proměnlivého pole vlhkostí (např. při infiltraci vody ze srážky) na polohu hladiny.

$\mathrm{V}$ naší studii je simulováno proudění $\mathrm{v}$ tělese hráze $\mathrm{s}$ použitím numerického modelu, který umožňuje řešit proudění vody $\mathrm{v}$ proměnlivě nasyceném heterogenním pórovitém prostředí, s obecnými okrajovými podmínkami.

Výsledky potvrdily, že př́istup, který uvažuje proudění i v nenasycené části hráze, lze k řešení průsaků zemními tělesy úspěšně využít.

KLÍČOVÁ SLOVA: záplavy, protipovodňová hráz, sypaná zemní hráz, nenasycená půda, vadózní zóna, modelování průsaku, vodní režim půd, Richardsova rovnice.

\section{Introduction}

Extreme floods represent an increased risk for urban areas, infrastructure, industrial structures and agriculture. Since the river embankments, polders and dams are often the only flood control measure, the safety of protective structures has attracted increased attention.
Time to time, the protective barriers along the rivers are destroyed by a suddenly increased amount of water with destructive or even catastrophic consequences (Rinaldi, Casagli, 1999). The most frequent causes of failures are overtopping, internal erosion, erosion of the banks and settling of the structure. Heavy rainfalls and rapid rise of water also cause wetting of unsaturated region in the up- 
per part of the structure which often ends up with slope failures.

Despite of today's advanced mathematical and computational capabilities, the predictions of seepage patterns are usually based merely on consideration of steady-state saturated zone beneath the phreatic surface. This assumption, even with introduction of finite element methods, is not accurate enough for fine grained soils. The key problem lies in determination of the position of phreatic surface in transient simulations, when water table level dramatically changes during extreme floods (Chen, Zhang, 2006). Generally, the seepage analysis belongs to the basic geotechnical problems which are related to seepage failures, contamination of ground water, slope stability issues, foundations and design of earthfill structures.

The first authors, who considered unsaturated hydraulic properties of soils for transient seepage analysis of earth dams, were Freeze (1971) and Neuman (1972). The inclusion of unsaturated zone in the modelling of seepage has practical consequences for engineering problems. Actual soil moisture conditions in vadose zone influence the position of water table, especially on fine grained soils (Szilagyi, 2004). This effect is significant for example in water regime of clay cores in earthfill dams or layered soil profiles (Starnaud, 1995). The flood events are commonly accompanied with heavy or long lasting rainfalls which may lead to saturation of the top soil at the surface of a dam body.

The permeability and shear strength of each soil vary with the degree of saturation. Thus saturated and nearly saturated conditions may cause reduction of stability of slopes, dams and earth dikes. Schmertmann (2006) provides a general engineering screening procedure to estimate the slope stability risk induced by atmospheric conditions such as rainfalls and droughts. Finite element hydromechanical numerical models are already being used in the river embankment stability studies (Rinaldi, Casagli, 1999; Dapporto et al., 2001; Pham, Fredlund, 2003), the earth dam seepage (Freeze, 1971; Thieu, 2000; Chen, Zhang, 2006) or the landslides simulations (Wilkinson et al., 2002; Gerscovich et al., 2006).

The aim of this study is to simulate the water dynamics in saturated and unsaturated zones of an arbitrary homogeneous earthfill dam during a flood event. A simple case was chosen. Any other more realistic dam structures (e.g. including clay core or material heterogeneities of any kind) may be simu- lated as well. The soil moisture propagation through a vertical cross section of the earth body during the flood event is simulated using the latest version of the numerical two-dimensional simulation model SWMS II (Vogel, 1987), the code S2D (Vogel et al., 2000).

\section{Theory}

The saturated-unsaturated soil water fluxes in a continuum of soil, air and water at the scale of representative elementary volume are being calculated according to Richards' flow equation. The equation is based on Darcy-Buckingham's law and continuity equation. Richard's equation for nearly laminar flow in variably saturated rigid porous media with incompressible water and continuous air phase with inclusion of root water uptake can be written as (Šimůnek et al., 2006):

$$
\frac{\partial \theta}{\partial t}=C(h) \frac{\partial h}{\partial t}=\frac{\partial}{\partial x_{i}}\left[K\left(K_{i j}^{A} \frac{\partial h}{\partial x_{j}}+K_{i z}^{A}\right)\right]-S,
$$

where $\theta$ is the volumetric water content $\left[\mathrm{L}^{3} \mathrm{~L}^{-3}\right], h-$ the pressure head $[\mathrm{L}], C$ - the moisture capacity $(\mathrm{d} \theta / \mathrm{d} h)\left[\mathrm{L}^{-1}\right], t$ - the time [T], $x_{i}(i=1,2)$ - the spatial coordinates $[\mathrm{L}], K-$ the unsaturated hydraulic conductivity function $\left[\mathrm{LT}^{-1}\right], K_{i j}{ }^{A}$ - components of a dimensionless anisotropy tensor $\mathbf{K}^{A}$ and $S$ is a sink term for root water extraction $\left[\mathrm{T}^{-1}\right]$.

The assumption of the air phase continuity has not to be always fulfilled when the soils are nearly saturated (Sněhota, 2003; Sněhota et al., 2008). Nevertheless, already Freeze (1971) showed that for simulation of seepage, when one is more interested in water fluxes than in air movement, inclusion of no more than the water phase is adequate and Eq. (1) may be used.

To solve transient flow problems we need to introduce relations between soil water content and pressure head (retention curve) and pressure head and hydraulic conductivity (hydraulic conductivity function). Both functions, called soil hydraulic characteristics, are commonly described by a set of parametric equations (van Genuchten (1980) and Mualem (1976)). Eq. (1) is a parabolic partial differential equation with highly nonlinear physical relationship between water content, pressure head and hydraulic conductivity, therefore is impossible to be solved analytically.

In the applied simulation model S2D a modification of retention curve is implemented (Vogel et al., 2001): 


$$
\theta(h)= \begin{cases}\theta_{r}+\left(\theta_{m}-\theta_{r}\right)\left(1+(-\alpha h)^{n}\right)^{-m} & h<h_{S} \\ \theta_{S} & h \geq h_{S}\end{cases}
$$

and

$$
K(h)=\left\{\begin{array}{cc}
K_{s} K_{r}\left(S_{e}(h)\right) & h<h_{s} \\
K_{s} & h \geq h_{s}
\end{array},\right.
$$

where:

$$
\begin{aligned}
& S_{e}(h)=\frac{\theta(h)-\theta_{r}}{\theta_{s}-\theta_{r}} \\
& K_{r}\left(S_{e}\right)=S_{e}^{1 / 2}\left(\frac{1-F\left(S_{e}\right)}{1-F(1)}\right)^{2} \\
& F\left(S_{e}\right)=\left(1-\left(\frac{\theta_{s}-\theta_{r}}{\theta_{m}-\theta_{r}} S_{e}\right)^{\frac{1}{m}}\right)^{m}
\end{aligned}
$$

in which $S_{e}$ is the effective soil water content, $\theta_{r}$ and $\theta_{s}$ - the residual and the saturated water contents $\left[\mathrm{L}^{3} \mathrm{~L}^{-3}\right], \theta_{m}-$ the extrapolated fictitious parameter $\left[\mathrm{L}^{3} \mathrm{~L}^{-3}\right]$ to allow non-zero air entry value $h_{s}$ $[\mathrm{L}], \alpha\left[\mathrm{L}^{-1}\right]$, the retention curve parameter $m$ is equal to $1-1 / n$ where $n>1 . K_{s}$ is the saturated hydraulic conductivity $\left[\mathrm{L} \mathrm{T}^{-1}\right]$ and $K_{r}$ - the relative hydraulic conductivity function.

The solution of Eq. (1) requires known initial distribution of the pressure head within the flow domain:

$$
h(x, z, t)=h_{0}(x, z) \text { for } t=0 .
$$

Two types of conditions were used to describe system independent interactions at the flow boundaries along the flow region (Vogel et al., 2004). These conditions are specified pressure head (Dirichlet type) boundary conditions in form:

$h(x, z, t)=\psi(x, z, t)$ for $(x, z) \in \Gamma_{\mathrm{D}}$

and specified the flux (Neumann type) boundary conditions given by:

$$
-\left[K\left(K_{i j}^{A} \frac{\partial h}{\partial x_{j}}+K_{i z}^{A}\right)\right] n_{i}=\sigma_{1}(x, z, t) \text { for }(x, z) \in \Gamma_{\mathrm{N}},
$$

where $\Gamma_{\mathrm{D}}$ and $\Gamma_{\mathrm{N}}$ indicate Dirichlet and Neumann boundary segments, $\Psi[\mathrm{L}], \sigma_{1}\left[\mathrm{~L} \mathrm{~T}^{-1}\right]$ are prescribed functions of $x, z$, and $t, n_{i}$ - the components of the outward unit vector normal to boundary $\Gamma_{\mathrm{N}}$.

S2D code numerically solves Richards' equation for saturated-unsaturated water flow. The numerical solution is based on Galerkin linear finite element method applied on a triangular elements mesh. The time derivatives are approximated by finite differences using a fully implicit approximation for both saturated and unsaturated conditions. The time step is adjusted automatically during the simulation to ensure stability and fulfilment of mass balance ( $\mathrm{VO}$ gel, 1987). The solution of the Richards equation gives the information about macroscopic spatiotemporal distribution of water content, pore pressures and water fluxes within the flow domain.

\section{Material and methods}

To illustrate the suitability of the numerical code and the saturated-unsaturated approach, we ran a numerical study to show the effect of a flood wave on water dynamics of protection embankment and its underlying subsoil. The simulation was performed by numerical model S2D (Vogel et al., 2000; Dušek et al., 2008).

The subject of the study is a protective homogeneous levee made of loamy-clay soil. The structure is founded on loamy top soil, which covers a deep layer of permeable sandy soil (see Fig. 1). The top of the dam is $2 \mathrm{~m}$ above terrain and $2.7 \mathrm{~m}$ above normal river water level, the width of the dam at the base is $12 \mathrm{~m}$. The waterside slope is $3: 1$, the landside slope is $2.5: 1$. There is a drain pipe beyond the toe of the dam. A draining ditch, which is often built up along the drain pipe, is not considered. The part behind the dam is enlarged to incorporate also the region where the possible upward flow caused by the flood event could take place. We consider no sealing layer at the contact with the river bed and the waterside slope.

The arrangement of soil horizons is typical for fluvial plains along lower parts of river basins. There the thick permeable alluvial layers are usually covered by the less permeable thin top soils. The top soil horizon serves as a natural antipercolation barrier and so offers the convenient material for foundation of a dam ( fortunately, especially in urban areas, the top layer is often spatially heterogeneous and may lead to preferential flow and preferential seepage below the dams. We do not consider preferential flow in this study. 


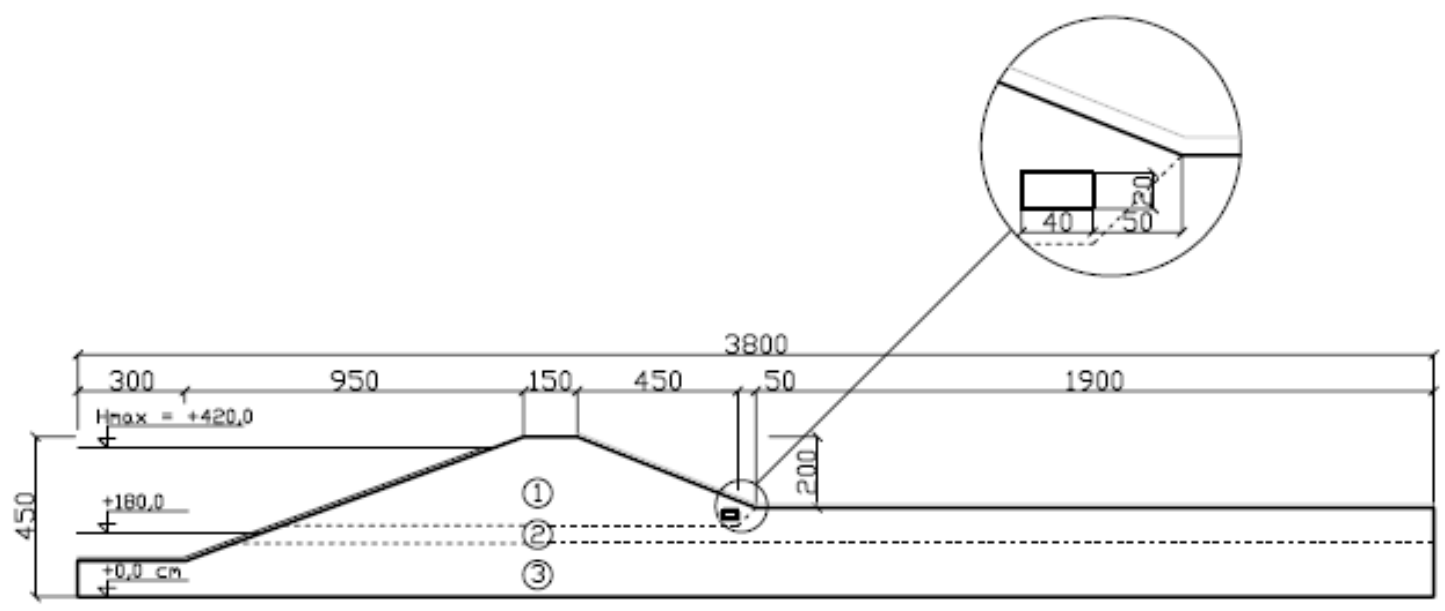

Fig. 1 Drawing of the simulated domain (in $\mathrm{cm}$ ). Dashed lines stand for three homogeneous soil materials. Obr. 1. Nákres modelované oblasti $(\mathrm{v} \mathrm{cm})$. Přerušované čáry vyznačují tři odlišné materiály.

$\mathrm{T} \mathrm{a} \mathrm{b} \mathrm{l} \mathrm{e} \mathrm{1.} \mathrm{Parameters} \mathrm{of} \mathrm{soil} \mathrm{hydraulic} \mathrm{characteristics.}$

$\mathrm{T}$ a b u $1 \mathrm{k}$ a 1 . Hydraulické charakteristiky.

\begin{tabular}{llcccccc}
\hline & Texture & $\theta_{r}$ & $\theta_{\mathrm{s}}$ & $\theta_{m}$ & $\alpha\left[\mathrm{cm}^{-1}\right]$ & $n$ & $K_{s}\left[\mathrm{~cm} \mathrm{~d}^{-1}\right]$ \\
\hline Earth dam body & loamy - clay & 0.095 & 0.41 & 0.415 & 0.019 & 1.31 & 6.24 \\
\hline $\begin{array}{l}\text { A horizon - loamy } \\
\text { sediments }\end{array}$ & loamy & 0.078 & 0.43 & 0.435 & 0.036 & 1.56 & 24.96 \\
\hline $\begin{array}{l}\text { B horizon - perme- } \\
\text { able alluvial layer }\end{array}$ & sandy - loam & 0.065 & 0.41 & 0.415 & 0.075 & 1.89 & 106.1 \\
\hline
\end{tabular}

The finite-element mesh was created with ARGUS ONE mesh generator. The triangular element mesh is composed of 45225 nodes and 89095 elements. The finite element mesh is finer (order of centimetres) at the waterside slope, where steep wetting front develops. The appropriate soil hydraulic characteristics of particular soil materials were taken from UNSODA database, the parameters are given in Tab. 1. Values of $\theta_{m}$ were assumed slightly higher than saturated water contents to incorporate air entry value (Vogel et al., 2001).

The propagation of the flood wave was simulated as a time-dependent pressure head boundary condition (Dirichlet type) prescribed at the waterside slope of the dam. The boundary nodes below the water level had given pressure head corresponding to the actual water level (Eq. (8)). The boundary conditions above the actual water level were assumed as no flow boundary (Neumann type, Eq. (9)). In this scenario we do not consider any rainfall or evapotranspiration, the both can be easily implemented in future simulations. The river water level position during the uprising and dropping stages were simplified by stepwise pressure function (13 steps, see Fig. 2). The simulated flood event lasts eight days, the maximum water level upraise was $240 \mathrm{~cm}$ at the flood wave peak. The shape of the wave (together with simulated course of water amount in the dam body) is on Fig. 2. Although the increase of the water level at the waterside slope is stepwise, the water flow within the simulated domain is transient.

To the landside slope terrain behind the dam and to the drain the seepage boundary condition was assigned. This condition assumes zero flux when the nodes at the boundary are under unsaturated conditions and zero pressure head during periods of full saturation. Zero flux boundary condition is prescribed to the remaining boundaries. We assume that the right edge of the domain is in a sufficient distance not to influence flow in the area of interest.

Initial condition (at the moment of the flood start) is prescribed as the equilibrium pressure field corresponding to the river water level position at $80 \mathrm{~cm}$.

\section{Results}

The results of the simulation are shown in Figs. 3,4 and 5. It can be noticed that the groundwater 


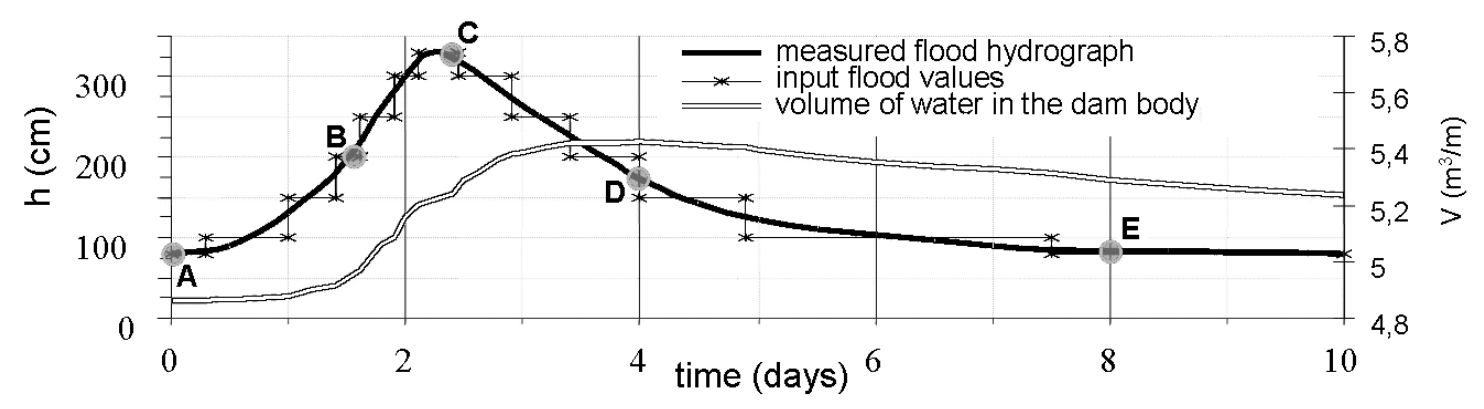

Fig. 2. Water level graph and the course of the volume of water in the levee. Asterix line shows the step approximation which was used as the input into the simulation model. Letters A to E correspond with marking in Figs. 3 and 4.

Obr. 2. Průběh hladiny na vodním líci ochranné hráze a objem vody v tělese hráze.

level (GWL) directly behind the toe of the dam increases by approximately $40 \mathrm{~cm}$ and continues to the drain pipe. For a given flood, GWL does not rise up to the surface behind the dam (this conclusion does not need to hold for longer lasting flooding).

During the flood event, which culminated on the third day at the water level of $320 \mathrm{~cm}$ (see Fig. 2), the $5.5 \mathrm{~m}^{3}$ of water was infiltrated per one length meter of the dam body. The maximum volume of water in the levee was four days after the beginning of the flood, when the water level in the river was already falling down (see Fig. 2).
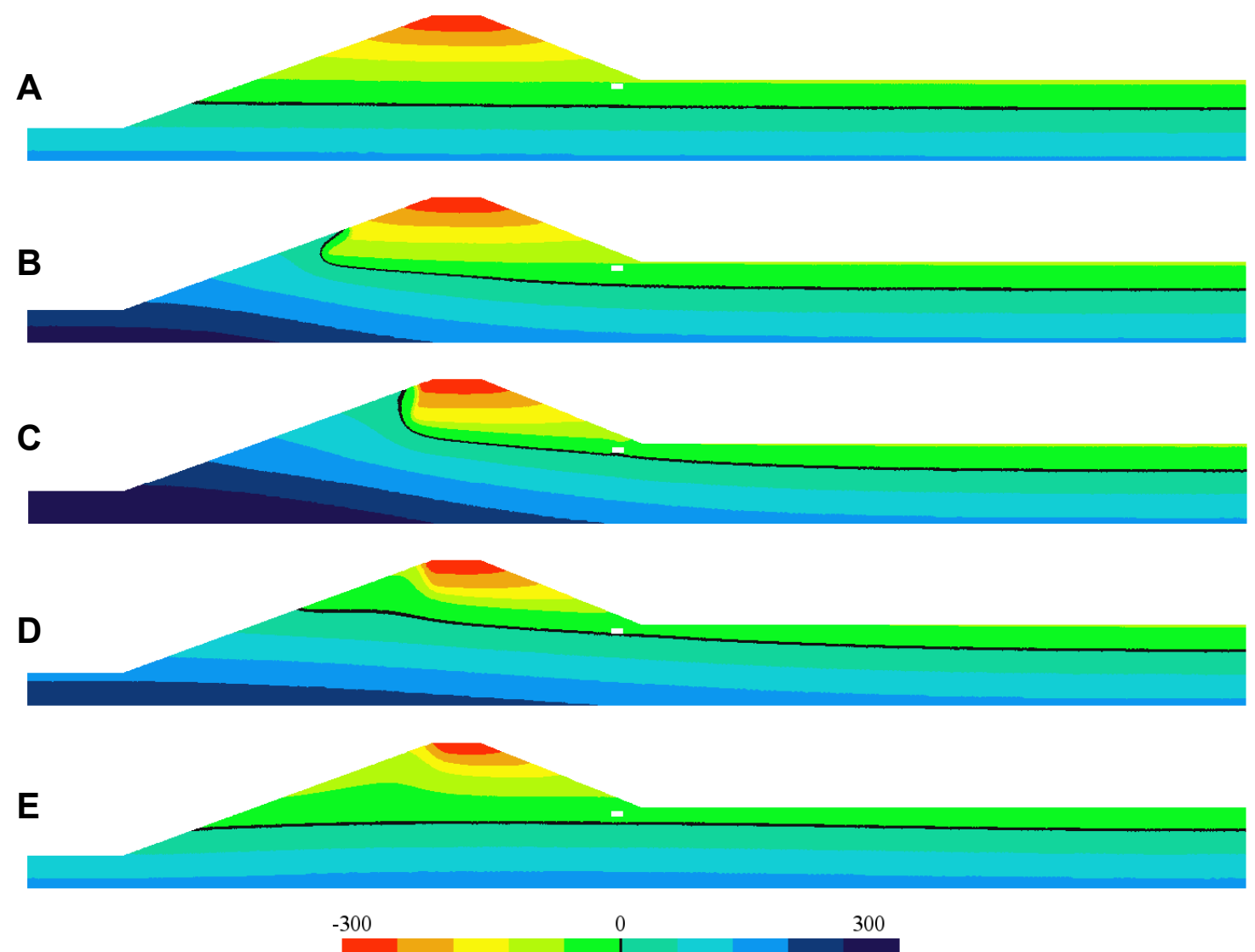

Fig. 3. Distributions of simulated pressure heads (cm) in particular times of the flood event A) 0; B) 1,6 days; C) 2,5 days; D) 4 days and E) 8 days after the beginning of the water level increase. The black solid line represents a phreatic surface.

Obr. 3. Rozložení modelovaných tlakových výšek $(\mathrm{cm}) \mathrm{v}$ reakci na povodňovou vlnu. Černá čára vyznačuje hladinu podzemní vody. 


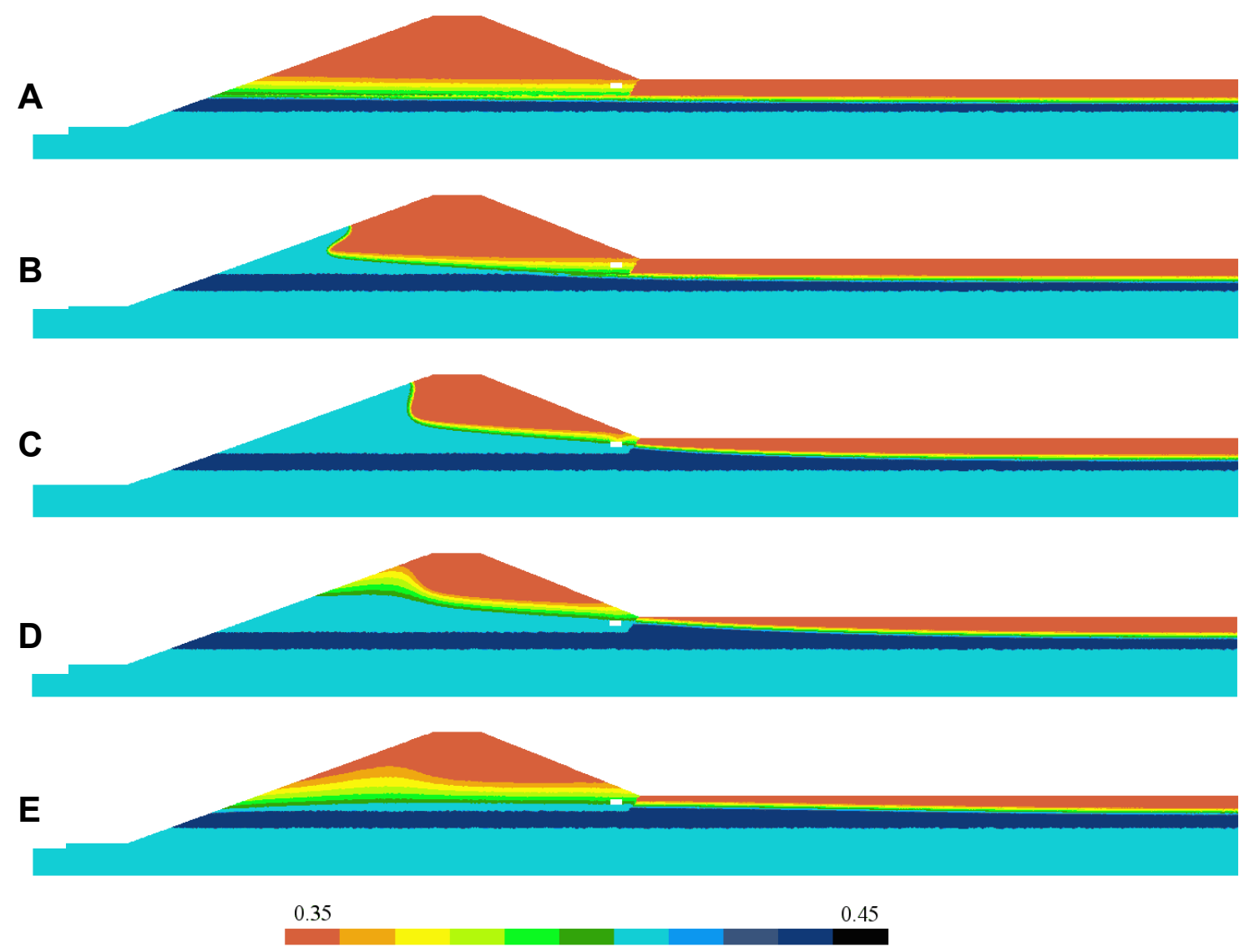

Fig. 4. Distributions of simulated soil water content in particular times of the flood event A) 0; B) 1.6 days; C) 2.5 days; D) 4 days and E) 8 days after the beginning of the water level increase.

Obr. 4. Rozložení modelovaných vlhkostí v reakci na povodňovou vlnu.

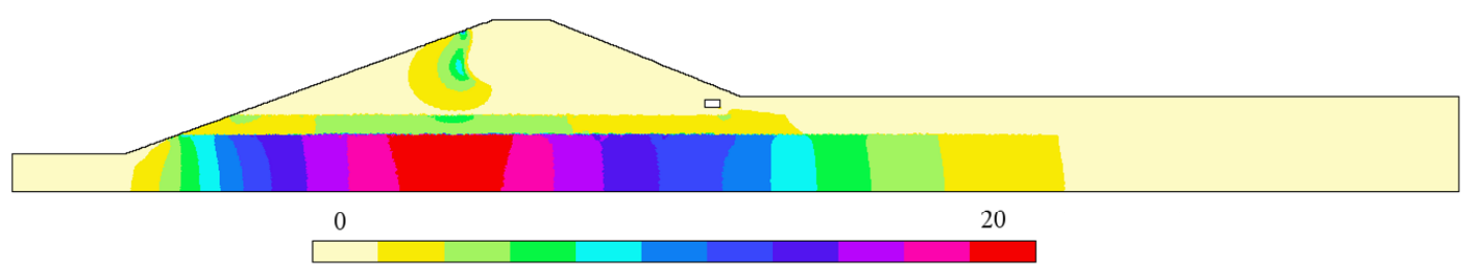

Fig. 5. Simulated field of horizontal velocities (in $\mathrm{cm} / \mathrm{d}$ ) at 2.5 days. The maximum velocities are reached in saturated permeable B horizon and at the wetting front.

Obr. 5. Modelované pole rychlostí proudění vody v horizontálním směru $(\mathrm{cm} / \mathrm{d})$.

In the Figs. 3 and 4 the simulated distribution of soil water pressure and water content in five selected stages of the flood event are presented. The $A$ part of the figures corresponds to the initial state at the start of the flood, the $B$ part shows the state during the flood rise, $C$ stands for the flood peak, $D$ for the maximum water volume in the dam structure when the level in the river is already decreasing, and $E$ is the state when water in the river is back at the initial state. The steady state conditions (the same as at the beginning of the simulation) are reached after approximately 40 days (not shown here).

Fig. 5 shows horizontal water flow velocities when the river water level was at its peak. At this moment the highest values of flow rates occure. In the saturated permeable sandy loam horizon the velocities reached the values of $20 \mathrm{~cm} \mathrm{~d}^{-1}$. The velocities at the water front are lower because of lower permeability of the particular soil considered 
to form the dam body. Even these magnitudes might be still significant for the potential waterside bank erosion.

\section{Conclusions}

Two-dimensional transient infiltration and seepage through the vertical cross section of the model protection embankment was simulated using variably saturated flow theory. The evolution of wetting front was expressed by means of pore-water pressure contours in different times. It has been shown that the proposed approach is not only a theoretical exercise, but it is a suitable procedure to be used in engineering applications.

Nonlinearity of Richard's equation is demanding in terms of computing time, hardware and experience. Input data for hydraulic characteristics are in most cases difficult and time consuming to obtain. Stability of the numerical solution is strongly dependent on proper design of finite element mesh, minimum allowed time increments in time discretization and detailed description of the flood wave formation. In any case, the presented methodology has still a strong potential to increase accuracy of the results of simulations in many real world applications, especially in those where fine grained soils are involved.

The transient simulations do result in a different velocity fields than the steady-state simulations. The steady-state approach cannot take into account the dynamics of water at the shallow layer of the dam slopes and at the wetting front. With increasing permeability of soil material the flux rates at the water front might become crucial. In contrast, the extreme flux rates in the permeable alluvial horizon are of the same magnitude as if they were simulated with a steady state approach. The transient approach provides the information not only about spatial but also temporal distribution of the critical velocities.

The simulation can be used for the design of earthfill structures with respect to different types of hydraulic failures. In the case of levees the most probable failures result from internal erosion and piping. The safety analysis may be done by comparing the simulated pore pressures and hydraulic gradients with the estimated critical values (Frank et al., 2004). The hydraulic gradients are not the direct outputs of the S2D model, but can be easily calculated from the velocities matrix. Values of velocity vectors at any node are available.
The simulation model S2D is suitable for engineering applications related to the earth dams due to its ability to describe the saturated and unsaturated flow complexly. As Freeze (1971) states, the failure to exclude unsaturated zone in transient analyses can lead to the results that are in error. Identifying the proper critical scenarios, the results of simulations using the model S2D may also help in designing of safe flood control dams or in evaluating reasons of possible failures to prevent future disasters.

The study is a part of the broader research with the aim to find out a methodology to simulate hydrological and soil mechanical behaviour of small earth dams and river embankments during extreme events. We also plan to propose a scheme for heterogeneity assessment of earth bodies based on geophysical tools to be able to incorporate the heterogeneity and preferential pathways into numerical simulations.

Acknowledgement. The research has been supported by project SP/2e7/229/07 and the Research Program of the Ministry of Education of the Czech Republic project no. VZ 04 CEZ MSM 6840770005. We would like to thank to Michal Dohnal and to anonymous reviewer for their helpful comments.

\section{REFERENCES}

CHEN Q., ZHANG L.M., 2006: Three-dimensional analysis of water infiltration into the Gouhou rockfill dam using saturated-unsaturated seepage theory. Can. Geotech. J., 43, 449$-461$.

DAPPORTO S., RINALDI M., CASAGLI N., 2001: Failure mechanisms and pore water pressure conditions: analysis of a riverbank along the Arno river (Central Italy). Engineering Geology, 61, 221-242.

DUŠEK J., GERKE H.H., VOGEL T., 2008: Surface Boundary Conditions in Two-Dimensional Dual-Permeability Modeling of Tile Drain Bromide Leaching. Vadose Zone J., 7, 4, 1287-1301.

FRANK R., BAUDUIN C., DRISCOLL R., KAWADAS M., KREBS OVESEN N., ORR T., SCHUPPENER B., 2004: Designers' guide to EN 1997-1 EUROCODE 7: Geotechnical design - general rules, Thomas Telford Ttd., London.

FREEZE R.A., 1971: Influence of the unsaturated flow domain on seepage through earth dams. Water Resources Research, 7, 4, 929-941.

GERSCOVICH D. M. S., VARGAS E. A., DE CAMPOS T. M.P., 2006: On the evaluation of unsaturated flow in a natural slope in Rio de Janeiro, Brasil. Engineering Geology, 88, 23-40.

MUALEM Y., 1976: A new model for predicting the hydraulic conductivity of unsaturated porous media. Water Resources Research, 12, 513-522. 
Soil moisture dynamics in levees during flood events - variably saturated approach

NEUMAN S.P., 1972: Saturated-unsaturated seepage by finite elements. Journal of the Hydraulics Division, 99, 12, 2233-2250 .

PHAM H.T.V., FREDLUND D.G., 2003: The application of dynamic programming to slope stability analysis. Canadian Geotechnical Journal, 40, 4, 830-847.

RINALDI M., CASAGLI N., 1999: Stability of streambanks formed in partially saturated soils and effects of negative pore water pressures: the Sieve River (Italy). Geomorphology, 26, 253-277.

Ř́lHA J., 2006: Flood protection - subterranean water problems. (In Czech.) Sborník z konference Vodní toky 2006, 38-43.

SCHMERTMANN J.H., 2006: Estimating slope stability reduction due to rain infiltration moulding. Journal of Geotechnical and Geoenvironmental Engineering, 132, 9, 1219$-1228$.

ŠIMU゚NEK J., VAN GEUNCHTEN M.TH., ŠEJNA J., 2006: The HYDRUS software package for simulating the twoand three-dimensional movement of water, heat, and multiple solutes in variably-saturated media, Technical manual, Version 1.0, PC Progress, Prague, Czech Republic.

SNĚHOTA M., 2003: Evaluation of infiltration-outflow experiment using MRI. [Doctoral Thesis.] Czech Technical University in Prague.

SNĚHOTA M., SOBOTKOVÁ M., CÍSLEROVÁ M., 2008: Impact of the entrapped air on water flow and solute transport in heterogeneous soil: Experimental set-up. J. Hydrol. Hydromech., 56, 4, p. 247-256.

STARNAUD G., 1995: The high pore pressures within embankment dams - an unsaturated soil approach. Canadian Geotechnical Journal, 32, 5, 892-898.

SZILAGYI, J., 2004: Vadose zone influences on aquifer parameter estimates on saturated-zone hydraulic theory. Journal of Hydrology, 286, 78-86.

THIEU, N. T. M., FREDLUND, D. G., HUNG, V. Q., 2000: General partial differential equation solvers for saturatedunsaturated seepage. In: Rahardjo H., Toll D.G., Leong E.C. (Eds.), Unsaturated Soils for Asia, 201-206.

VAN GENUCHTEN M.TH., 1980: A closed-form equation for predicting the hydraulic conductivity of unsaturated soils. Soil Sci. Soc. Am. J., 44, 892-898.

VOGEL T., 1987: SWMS II - Numerical model of twodimensional flow in a variably saturated porous medium. Research Report No. 87, Dept. of Hydraulics and Catchment Hydrology, Agricultural Univ., Wageningen, The Netherlands.

VOGEL T., GERKE H.H., ZHANG R., VAN GENUCHTEN M.TH., 2000: Modeling flow and transport in a twodimensional dual-permeability system with spatially variable hydraulic properties. Journal of Hydrology, 238, 1-2, 78-89.

VOGEL T., VAN GENUCHTEN M.TH., CÍSLEROVÁ M., 2001: Effect of the shape of the soil hydraulic functions near saturation on variably-saturated flow predictions. Advances in Water Resources, 24, 133-144.

VOGEL, T., DOHNAL, M., DUŠEK, J., 2004: Bench scale modeling approaches. Research Report C1.1, Eberhard Karls Universität Tübingen.

WILKINSON P.L., ANDERSON M. G., LLOYD D.M., 2003: An integrated hydrological model for rain-induced landslide prediction. Earth Surface Processes and Landforms, 27, 12, 1285-1297.

Received 19 February 2009

Accepted 14 October 2009

\section{DYNAMIKA VODNÍHO REŽIMU V TĚLESE OCHRANNÉ HRÁZE BĚHEM POVODNĚ S UVÁŽENÍM NENASYCENÉHO PROUDĚNÍ}

\section{David Zumr, Milena Císlerová}

Vyšší pravděpodobnost výskytu extrémních klimatických jevů obrací pozornost $\mathrm{k}$ ochraně před následky, které tyto jevy způsobují. Zájem se soustředí na protipovodňové ochranné zemní hráze a jejich bezpečnost při povodních. Výpočet průsaku zemními hrázemi se často omezuje pouze na tu část hráze, která byla plně nasycená vodou, to znamená na plně nasycené proudění. Tento způsob modelování průsaku je dodnes považován za standardní, přestože je velmi limitující. Na význam nenasycené zóny na průběh průsaků hrází a na dynamiku tlakových poměrů uvnitř tělesa hráze upozornila celá řada autorů (např. Freeze, 1971; Dapporto et al., 2001). Zahrnutí nenasycené zóny je velmi důležité zejména u jemnozrnných, málo propustných zemin, ze kterých jsou často budována jádra zemních hrází. Bez zahrnutí nenasycené č́sti tělesa hráze je zanedbán vliv časově i prostorově proměnlivého pole vlhkostí (např̀. při infiltraci vody ze srážky) na polohu hladiny.

V naší studii je simulováno proudění $\mathrm{v}$ tělese hráze s použitím numerického modelu, který umožňuje řešit proudění vody $\mathrm{v}$ proměnlivě nasyceném heterogenním pórovitém prostředí, s obecnými okrajovými podmínkami. Pro ilustraci použitelnosti př́stupu byla zvolena geologická skladba vrstev podloží typická pro údolní nivy dolních tratí větších toků, tak jak ji popisuje např́klad Říha (2006). Jedná se o mocné vrstvy velmi propustných sedimentů, které jsou překryty vrstvami málo propustných povodňových hlín (obr. 1).

Průběh povodňové vlny byl simulován pomocí proměnlivé okrajové podmínky na návodním líci hráze. Okrajová podmínka byla $\mathrm{v}$ zatopené části definována jako předepsaná tlaková výška (Dirichletova podmínka), která se skokově měnila podle aktuální výšky zatopení (obr. 2). Nezatopené části návodního líce byla přiřazena atmosférická okrajová podmínka (Neumanova). Na horním okraji hráze byla nastavena atmosférická okrajová podmínka, za hrází a v patě hráze výronová plocha. Tok dnem i horizontální tok podložím byly uvažovány jako nulové. Bylo simulováno celkem čtyřicet dní, během simulovaného období nebyly uvažovány žádné srážky ani výpar. Pro řešení byl použit simulační model S 2D DUAL (Vogel et al., 2000), který využívá metody konečných elementů pro prostorovou diskretizaci a konečných diferencí pro diskretizaci času.

Výsledky simulace jsou na obr. 3, 4 a 5. Během povodně, která kulminovala ve třetím dni na stavu $320 \mathrm{~cm}$, bylo do tělesa hráze infiltrováno přes $5,5 \mathrm{~m}^{3}$ vody na metr šiřky hráze. Nejvíce vody bylo v hrázi čtyři dny po 
začátku povodně, kdy hladina $\mathrm{v}$ korytu řeky již klesala (obr. 2).

Dynamika infiltrace vody do tělesa hráze a do podloží je ilustrována na obr. 3 a 4. Obr. 3 vyjadřuje rozložení tlakových výšek ve vybraných časech, na obr. 4 jsou odpovídající aktuální vlhkosti. Př́ípad (a) odpovídá počátečnímu ustálenému stavu, (b) stavu během vzestupu hladiny, (c) kulminaci povodňové vlny, (d) maximálnímu objemu zadržené vody v tělese hráze a (e) stavu po opadnutí vlny.

Výsledky potvrdily, že přístup, který uvažuje proudění i v nenasycené části hráze, lze $\mathrm{k}$ řešení průsaků zemními tělesy úspěšně využít při aplikacích, které vyžadují podrobnou znalost vodního režimu i v nenasycené zóně. Jedná se např́iklad o zjišt'ování tlaků vody $\mathrm{v}$ pórech během sycení a prázdnění zemních hrází pro posuzování stability těles, modelování vývoje vlhkosti jílových jader v nehomogenních hrázích při nízkých nebo nulových stavech $\mathrm{v}$ nádrži, kdy hrozí nebezpečí vzniku puklin vlivem vysušení. Model dovoluje testovat vliv různého počátečního nasysení ochranných hrází nebo hrází poldrů a vliv infiltrace deštové vody.
Seznam symbolì

\begin{tabular}{|c|c|}
\hline$\theta$ & - objemová vlhkost $\left[\mathrm{L}^{3} \mathrm{~L}^{-3}\right]$, \\
\hline$h$ & - tlaková výška [L], \\
\hline$C$ & - vlhkostní kapacita $\left[\mathrm{L}^{-1}\right]$, \\
\hline$t$ & - čas $[\mathrm{T}]$ \\
\hline$x_{i}(i=$ & - prostorové souřadnice [L], \\
\hline$K$ & - nenasycená hydraulická vodivost $\left[\mathrm{L} \mathrm{T}^{-1}\right]$, \\
\hline$K_{i j}{ }^{A}$ & - složky tenzoru anisotropie, \\
\hline$S$ & $\begin{array}{l}\text { - propadový člen pro odběr vody kořenovou zónou } \\
{\left[\mathrm{T}^{-1}\right],}\end{array}$ \\
\hline$S_{e}$ & - stupeň nasycení, \\
\hline$\theta_{r}$ & - residuální vlhkost $\left[\mathrm{L}^{3} \mathrm{~L}^{-3}\right]$, \\
\hline$\theta_{s}$ & - nasycená vlhkost $\left[\mathrm{L}^{3} \mathrm{~L}^{-3}\right]$ \\
\hline$\theta_{m}$ & - parametr modifikované retenční křivky $\left[\mathrm{L}^{3} \mathrm{~L}^{-3}\right]$, \\
\hline$h_{s}$ & - vstupní hodnota vzduchu [L], \\
\hline$\alpha$ & $\begin{array}{l}\text { - parametr retenční křivky podle van Genuchtena } \\
{\left[\mathrm{L}^{-1}\right],}\end{array}$ \\
\hline$m$ & - parametr retenční křivky podle van Genuchtena, \\
\hline$n$ & - parametr retenční křivky podle van Genuchtena, \\
\hline$K_{s}$ & - nasycená hydraulická vodivost $\left[\mathrm{L} \mathrm{T}^{-1}\right]$ \\
\hline$K_{r}$ & - funkce relativní hydraulické vodivosti, \\
\hline$\Gamma_{\mathrm{D}}$ & - Dirichletova okrajová podmínka, \\
\hline$\Gamma_{\mathrm{N}}$ & - Neumannova okrajová podmínka, \\
\hline$\Psi, \sigma_{1}$ & - předepsané funkce $[\mathrm{L}],\left[\mathrm{L} \mathrm{T}^{-1}\right]$. \\
\hline
\end{tabular}

